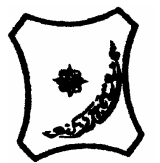

Bayero Journal of Pure and Applied Sciences, 4(2): 192 - 198

Received: August, 2011

Accepted: December, 2011

ISSN $2006-6996$

\title{
GEOELECTRIC INVESTIGATION OF SUBSURFACE STRUCTURE OF ACADEMIC AREA OF THE OLD CAMPUS OF BAYERO UNIVERSITY KANO FOR OPTIMIZED CITING OF BOREHOLES
}

\author{
${ }^{1}$ Oritsejolonesan, 0 . U. and ${ }^{2}$ Saleh, $M$. \\ ${ }^{1}$ General Studies Unit, Federal Polytechnic Ekowe, Bayelsa State, Nigeria. \\ ${ }^{2}$ Department of Physics, Bayero University, Kano, Kano-Nigeria. \\ *Correspondence author: muhmusabi@yahoo.co.uk
}

\begin{abstract}
Apparent Resistivity and Self Potential data were acquired from the study area using vertical electrical sounding technique about square grid of $100 \mathrm{~m}$ size within the academic area of Old Campus of Bayero University, Kano, Nigeria. The area is located between Latitude $11^{0} 59^{\prime} 00.7^{\prime \prime} \mathbf{N}$ to $11^{0} 58^{\prime} 49.2^{\prime \prime} \mathrm{N}$ and Longitude $8^{0} 28^{\prime} 35.3^{\prime \prime} \mathrm{E}$ to $8^{0} 29^{\prime} 00.8^{\prime \prime} E$. The collected data were analyzed using IP12WIN, Surfer version 7.0, and MS Excel. The study enabled us to generate graphical display of groundwater flow pattern and basement rock topography in the study area. Review of past groundwater exploration activities showed that the maximum drilling depth of boreholes within the investigation area was $42.0 \mathrm{~m}$. However, this study, based on the acquired data analyzed, recommended for drilling depth of about 60.0 to $80.0 \mathrm{~m}$ and in addition identified locations of possible higher/sustainable yield. Thus, this study will consequently help in optimized citing of boreholes and curtail unwarranted spending from indiscriminate and shallow sinking of boreholes. The study identified the areas between Biology Department and Central Mosque, and around Sports Complex for groundwater exploitation activities.

Keywords: Apparent, Optimized, Resistivity, Sounding and Vadose.
\end{abstract}

\section{INTRODUCTION}

Water is one of the basic needs of life. Historically, past settlements are normally clustered around water sources. As the population grows and expands, the need for water equally increases. Modernization brings about better development for provision of portable water to attain to challenges posed by such increasing population through pipe-borne water. As the population increases further, network for water supply becomes more complex. Maintenance of existing and development of new water supply facilities to attend to pressure posed by such increases is unbearably difficult and expensive. This is the problem bedeviling most parts of Kano; including Bayero university old campus. These lead to increase in number of boreholes and hand-dug well within the campus. Most if not all of the wells are unproductive due to high rise in boreholes. Now boreholes have dotted the campus, demonstrating poor/no plan in groundwater exploitation/development activities.

Digging of wells is a wildcat activity whereas surface geophysical methods provided a means of probing the subsurface by means of indirect studying of conductivity of the region and therefore are being used to find suitable locations for boreholes. Geophysical data greatly help in locating the groundwater potential in any hydro geological set up. This forms the basis of borehole geophysics (Kasonta and Kasonta, 1999). This technique has been successfully used in the exploration for groundwater in a sedimentary environment in Nnanka, Anambra (Emenike, 2001); in accessing groundwater potentials in basement complex rocks at Kwasauri near Kano. (Alkali, Kamfut and Yusuf, 1997) and for ground water exploration in Ikorodu, Lagos (Obiora and Onwuka, 2005). In the present work two electrical methods, Self-Potential (SP) and direct-current (DC) resistivity, were used to study the subsurface condition of the academic area of old campus of Bayero University, Kano in order to provide a stronger basis for stratigizing underground water exploration/exploitation and other earthworks within the campus.

\section{Geology and Hydrogeology of the Study Area} Bayero University Kano has the same geology as Kano in general. Its geology consists of basement complex mainly. The rock types in the area are older granites sediments and older basement. The older basement is composed of migmatite, biotite gneiss, and blended gneiss. Migmite is composite gneiss produced by injection of molten magma in to schist host. Gneiss is metamorphosed granite and is grantic in composition, while biotite gneiss is a foliated crystalline rock with high biotite content. Banded gneiss has light and dark bands with a light fraction of quartz while the dark bands consist of biotite plagiodase and minerals (www.kanostate.net, 2001) 


\section{Location of the Study Area}

Bayero University Kano old campus is in Gwale local government Area of Kano state, Nigeria. It is in the southwestern outskirts of the old Kano city. The study area is located between Latitude $11^{0} 59^{\prime} 00.7^{\prime \prime} \mathrm{N}$ to $11^{0} 58^{\prime} 49.2^{\prime \prime} \mathrm{N}$ and Longitude $8^{0} 28^{\prime} 35.3^{\prime \prime} \mathrm{E}$ to $8^{0} 29^{\prime} 00.8^{\prime \prime} E$.

The following were the aims and objectives of this work;

- To locate groundwater patterns within BUK old campus to give relevant information that will guide borehole drilling within the campus.

- To map the general overburden stratigraphy of BUK old campus.

- To ascertain the depth to the basement and map the basement topography of BUK old campus.

- To develop a general conceptual model of the site of investigation.

\section{MATERIALS AND METHODS Self Potential}

Self Potential can also be referred to as spontaneous potential. It occurs when no current is injected and yet there are potential measurements on the potential electrode. It can be due to manmade disturbances of the environment such as buried electrical cables, drainage pipes or waste disposal sites (William, 1997). Other self potentials are natural effects due to mechanical or electrochemical action. When an electrolyte is forced to flow through a narrow pipe, a potential difference (voltage) may arise between the ends of the pipe. Its amplitude depends on the electrical resistivity and viscosity of the electrolyte and on pressure difference that cause the flow.

\section{Apparent Resistivity}

The method involves measuring ground resistivity by simultaneously passing current into the ground via two current electrodes and measuring voltage created by the current flow in the vicinity of the electrodes using two neighboring potential electrodes. The earth has high resistance which is usually lowered by presence of conductive materials and special meters that have high impedance are used in resistivity methods application. Such a voltmeter draws virtually no current, and the voltage drop through the electrodes is therefore negligible. The resistances at the current electrodes limit current flow but do not affect resistivity calculations. A geometric factor is needed to convert the readings obtained with these four-electrode arrays to resistivity.

The result of any single measurement with any array could be interpreted as due to homogeneous ground with a constant resistivity. The geometric factors used to calculate this apparent resistivity, $\rho$, can be derived from the formula (John, 2003)

$$
V=\frac{\rho I}{2 \pi a}
$$

for the electric potential $V$ at a distance $a$ from a point electrode at the surface of a uniform half-space (homogeneous ground) of resistivity $\rho$ (referenced to a zero potential at infinity). The current $I$ may be positive (if into the ground) or negative. For arrays, the potential at any voltage electrode is equal to the sum of the contributions from the individual current electrodes.

In a four-electrode survey over homogeneous ground (Keller and Frischnecht, 1966) the expression for $\mathrm{K}$ is as given in equation (2).

$$
K=\frac{2 \pi}{\frac{1}{\overline{A M}}-\frac{1}{\overline{B M}}-\frac{1}{\overline{A N}}-\frac{1}{\overline{B N}}}
$$

Geometric factors $\mathrm{K}$ are not affected by interchanging current and voltage electrodes and voltage electrode spacings are normally kept small to minimize the effects of natural potentials (John, 2003).

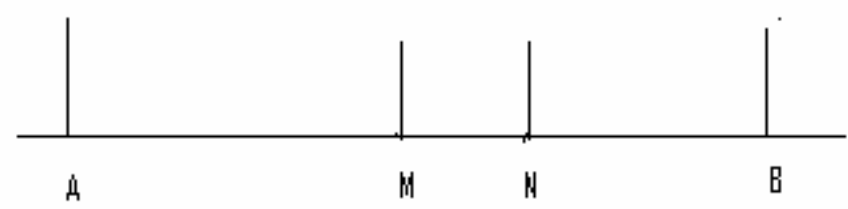

\section{Data Analysis}

The results from the 15 soundings were separated into the SP and the apparent resistivity, and analyzed with various computer softwares.

The field data for point number 1 is given in Table 1 . The self potential results were analyzed directly with Microsoft excel plotting the SP $(\mathrm{mV})$ against $A B / 2(\mathrm{~m})$ with $A B / 2$ being the depth of investigation. The resistivity values were inputted into IP12WIN

\section{ger Electrode array}

resistivity analysis software and modeled, giving rise to eleven layers and thicknesses of each layer. The modeled depths were then inputted into surfer 7.0 software and interpolated to generate contour maps. The various points were placed along horizontal points of $100 \mathrm{~m}$ apart as indicated with Figure 2, with five profiles arrived at to get the horizontal cross section of the study area. 


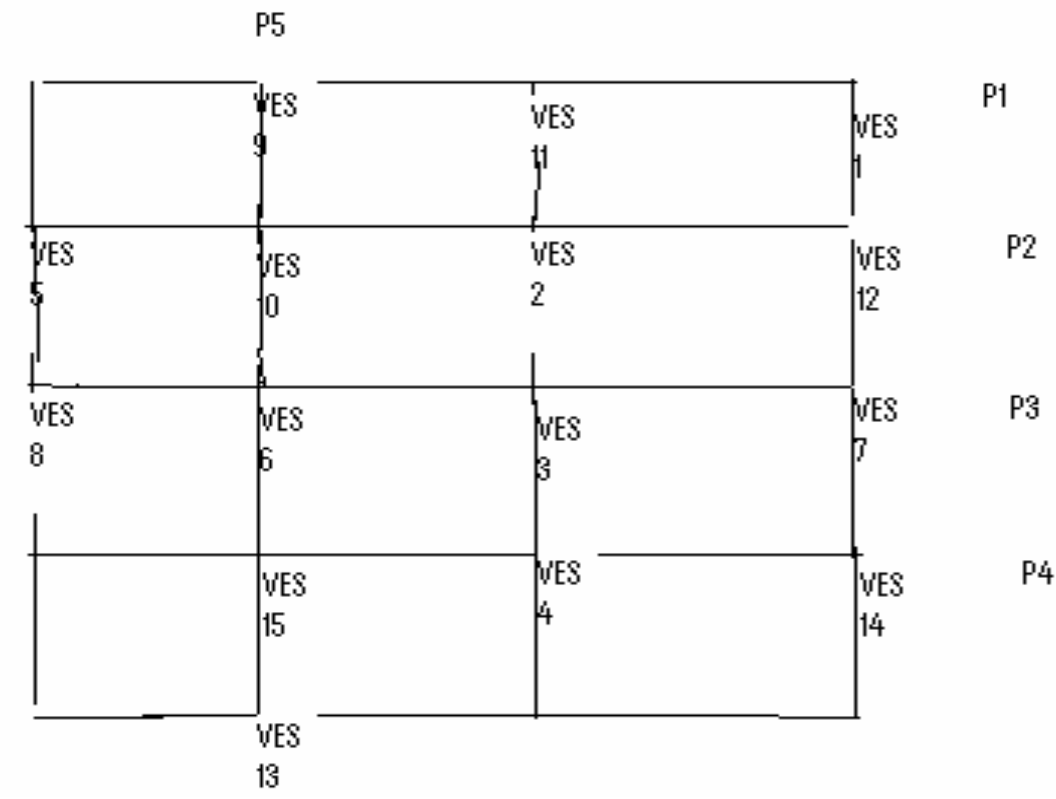

Figure 2: Distribution points of $100 \mathrm{~m}$ apart of VES points

Table 1: Field data for VES 1

\begin{tabular}{lllll}
\hline $\mathbf{S} / \mathbf{N}$ & $\begin{array}{l}\mathbf{A B} / \mathbf{2} \\
\mathbf{( m )}\end{array}$ & $\begin{array}{l}\mathbf{M N} / \mathbf{2} \\
(\mathbf{m})\end{array}$ & $\mathbf{S P}(\mathbf{m v})$ & $\mathbf{p}(\mathbf{\Omega m})$ \\
\hline 1 & 1.5 & 0.5 & 1.346 & 78 \\
2 & 2 & 0.5 & 0.367 & 304.73 \\
3 & 3 & 0.5 & 0.552 & 236.07 \\
4 & 4 & 0.5 & 0.478 & 219 \\
5 & 6 & 0.5 & 0.634 & 245.85 \\
6 & 7 & 0.5 & 0.752 & 160.74 \\
7 & 8 & 0.5 & 0.941 & 24.334 \\
8 & 10 & 0.5 & 0.884 & 284.64 \\
9 & 10 & 2 & 0.637 & 280.67 \\
10 & 12 & 2 & 0.594 & 335.13 \\
11 & 14 & 2 & 0.633 & 448.55 \\
12 & 15 & 2 & 0.164 & 324.04 \\
13 & 17 & 2 & 0.357 & 474.28 \\
14 & 20 & 2 & 0.241 & 268.97 \\
15 & 25 & 2 & 0.678 & 232.62 \\
16 & 30 & 2 & 0.547 & 753.1 \\
17 & 35 & 2 & 0.663 & 356.66 \\
18 & 40 & 2 & 0.412 & 894.2 \\
19 & 45 & 2 & 0.763 & 1405.4 \\
20 & 45 & 10 & 0.674 & 128.849 \\
21 & 60 & 10 & 1.521 & 28.449 \\
22 & 70 & 10 & 0.537 & 789.83 \\
23 & 100 & 10 & 0.937 & 1149 \\
24 & 120 & 10 & 0.437 & 1405 \\
\hline & & & &
\end{tabular}




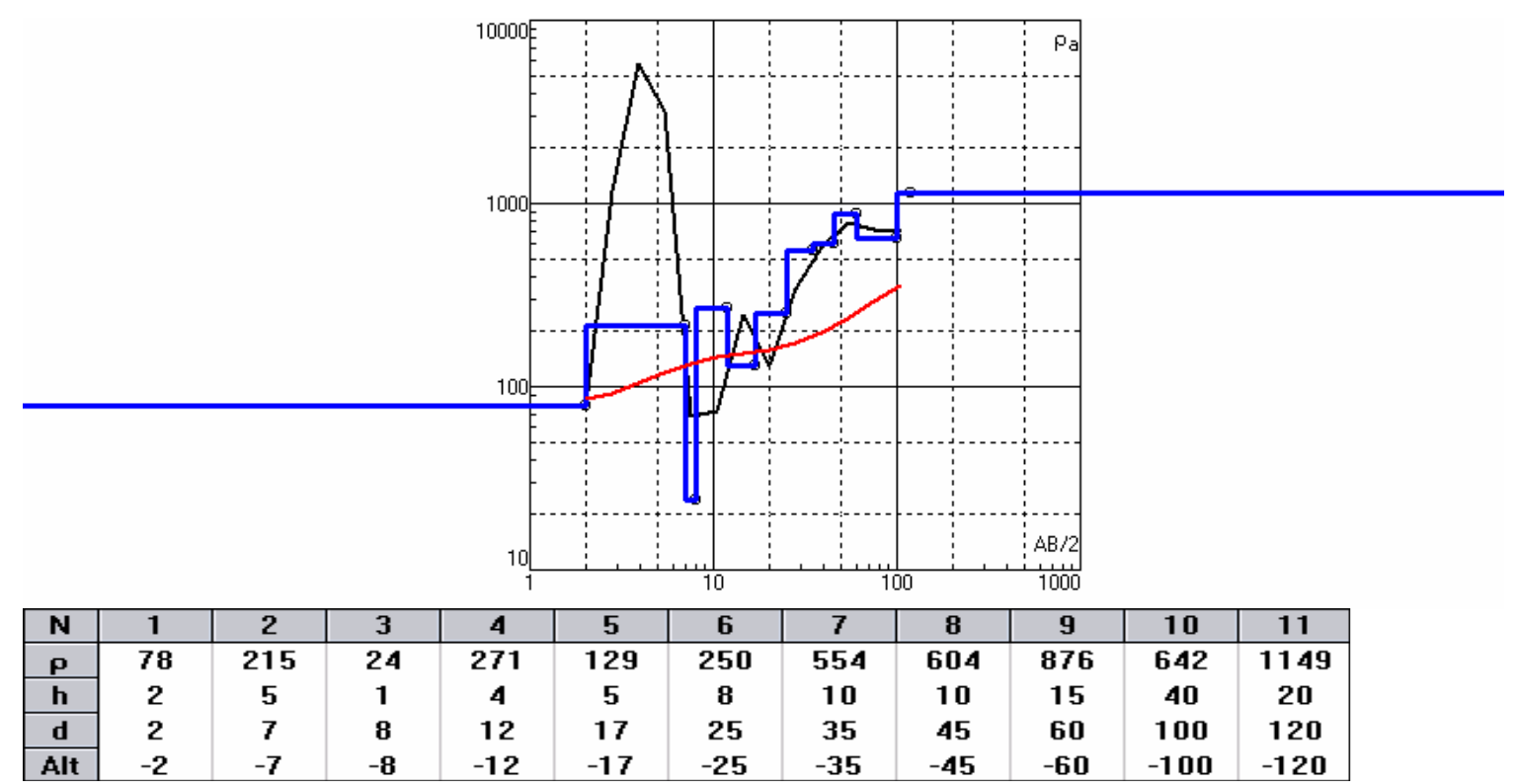

Figure 3: VES Curves and Model data for point number 1

Table 2: Metadata for the Investigation Points

\begin{tabular}{|c|c|c|c|c|}
\hline VES & Lat. $\mathbf{N}$ & Long. E & Elev. (m) & Remarks \\
\hline 1 & $11^{\circ} 58^{\prime} 43.1^{\prime \prime}$ & $8^{\circ} 28^{\prime} 36.9^{\prime \prime}$ & 432 & $\begin{array}{l}\text { Behind the proposed new faculty of Medicine, while } \\
\text { approaching the small gate leading to Janbulo. }\end{array}$ \\
\hline 2 & $11^{\circ} 58^{\prime} 47^{\prime \prime}$ & $8^{\circ} 28^{\prime} 38.4^{\prime}$ & 490 & $\begin{array}{l}\text { On the foot path that leads to the overhead } \\
\text { tank/borehole behind the food selling points. }\end{array}$ \\
\hline 3 & $11^{\circ} 58^{\prime} 52.6^{\prime \prime}$ & $8^{\circ} 28^{\prime} 42.5^{\prime \prime}$ & 476 & Very close to the transformer in the boys' hostel. \\
\hline 4 & $11^{\circ} 58^{\prime} 54.9^{\prime \prime}$ & $8^{\circ} 28^{\prime} 36.9^{\prime \prime}$ & 461 & In front of the laundry. \\
\hline 5 & $11^{\circ} 58^{\prime} 47.3^{\prime \prime}$ & $8^{\circ} 28^{\prime} 53.3^{\prime \prime}$ & 494 & $\begin{array}{l}\text { In between the main Mosque and Biochemistry } \\
\text { department. }\end{array}$ \\
\hline 6 & $11^{\circ} 58^{\prime} 52.3^{\prime \prime}$ & $8^{\circ} 28^{\prime} 45.9^{\prime \prime}$ & 493 & $\begin{array}{l}\text { In between the boys' hostel and the tarred road at } \\
\text { the point close to the side of the MBA block. }\end{array}$ \\
\hline 7 & $11^{\circ} 58^{\prime} 54.3^{\prime \prime}$ & $8^{\circ} 28^{\prime} 54.3^{\prime \prime}$ & 478 & K block boys hostel by PG hall entrance. \\
\hline 8 & $11^{\circ} 58^{\prime} 51.7^{\prime \prime}$ & $8^{\circ} 28^{\prime} 50.3^{\prime \prime}$ & 482 & In front of the pavement to the main library. \\
\hline 9 & $11^{\circ} 58^{\prime} 42.5^{\prime \prime}$ & $8^{\circ} 28^{\prime} 51.5^{\prime \prime}$ & 488 & $\begin{array}{l}\text { By the drainage on the road connecting health } \\
\text { centre/chemistry laboratory to the main gate. }\end{array}$ \\
\hline 10 & $11^{\circ} 58^{\prime} 42.3^{\prime \prime}$ & $8^{\circ} 28^{\prime} 351.6$ & 492 & In between Theatre $2 \& 3$ and Physiology laboratory. \\
\hline 11 & $11^{\circ} 58^{\prime} 42.8^{\prime \prime}$ & $8^{\circ} 28^{\prime} 40.8^{\prime \prime}$ & 488 & $\begin{array}{l}\text { Beside the proposed new faculty of Medicine by the } \\
\text { gate of the barbed wire fence. }\end{array}$ \\
\hline 12 & $11^{\circ} 58^{\prime} 52.1^{\prime \prime}$ & $8^{\circ} 28^{\prime} 37^{\prime \prime}$ & 512 & $\begin{array}{l}\text { Its location is behind PG hall by the road to the } \\
\text { back gate leading to Gwarzo road. }\end{array}$ \\
\hline 13 & $11^{\circ} 59^{\prime} 02.9^{\prime \prime}$ & $8^{\circ} 28^{\prime} 50.3^{\prime \prime}$ & 491 & $\begin{array}{l}\text { Sports complex along the foot path to the small } \\
\text { gate leading to Gwarzo road. }\end{array}$ \\
\hline 14 & $11^{\circ} 58^{\prime} 43.1^{\prime \prime}$ & $8^{\circ} 28^{\prime} 36.9^{\prime \prime}$ & 491 & West side of the laundry. \\
\hline 15 & $11^{\circ} 58^{\prime} 55.5^{\prime \prime}$ & $8^{\circ} 28^{\prime} 09.8^{\prime \prime}$ & 507 & $\begin{array}{l}\text { East of the MSS mosque entrance, behind the } \\
\text { kiosk. }\end{array}$ \\
\hline
\end{tabular}

Table 3: Derived Resistivity Values

\begin{tabular}{lll}
\hline Layer & Resistivity Range $(\mathbf{m})$ & Type of Material \\
\hline 1 & $10-100$ & Top Soil (Silty sandy soil) \\
2 & $101-200$ & Laterite \\
3 & $201-400$ & Highly Weathered Basement \\
4 & $401-750$ & Partially weathered Basement \\
5 & 800 and above & Fresh Basement \\
\hline
\end{tabular}




\section{RESULTS}

Figure 4 shows the geological section of profile one (P1). The disposition of the profiles in relation to each other is depicted in Figure 2. Alongside the geological section are the SP data plots corresponding to the VES points in profile 1 (Figure 5 ).

\section{VES POINT NUMBER}

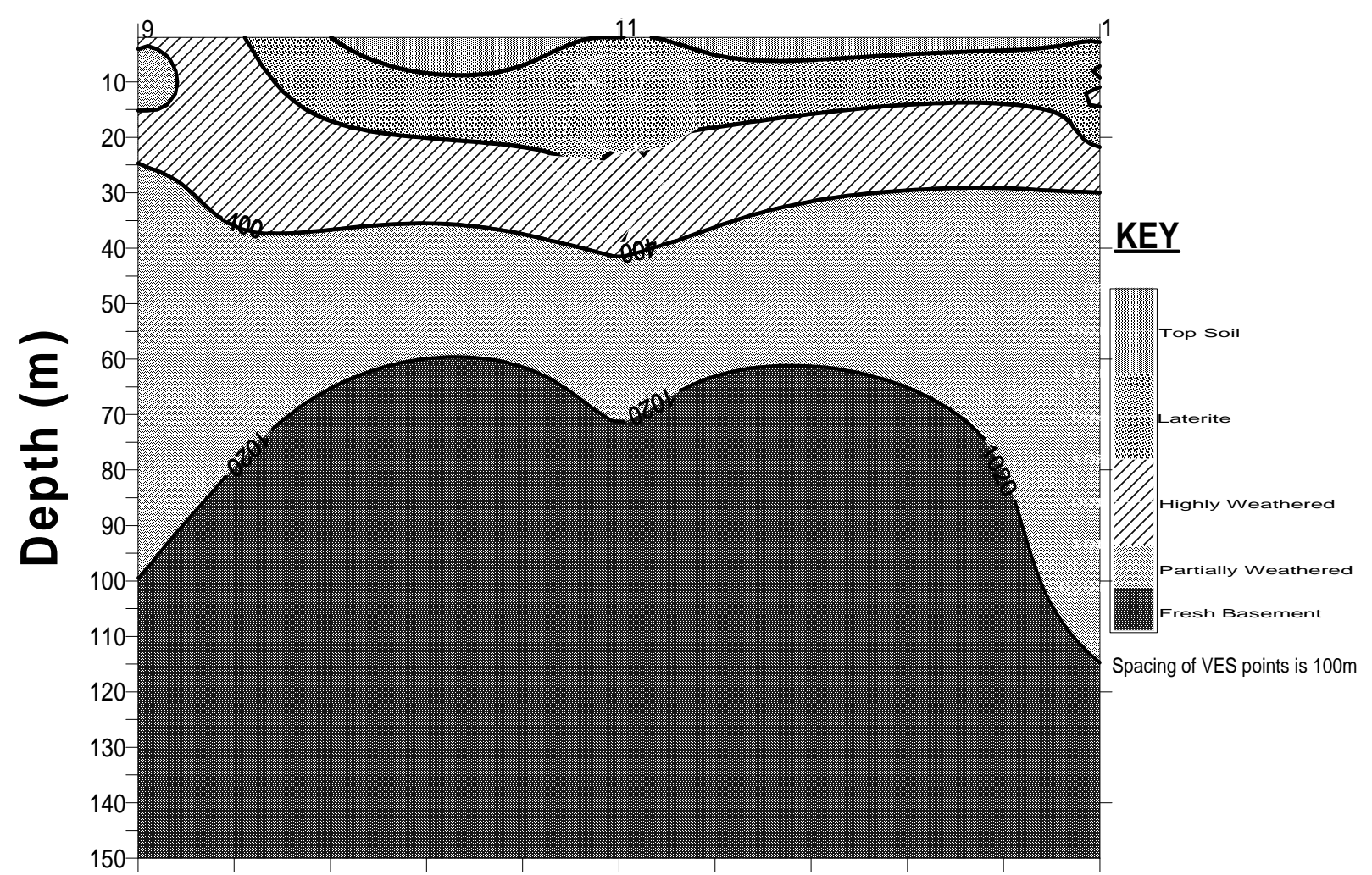

Figure 4: Pseudo-section/Geologic Section of first profile.
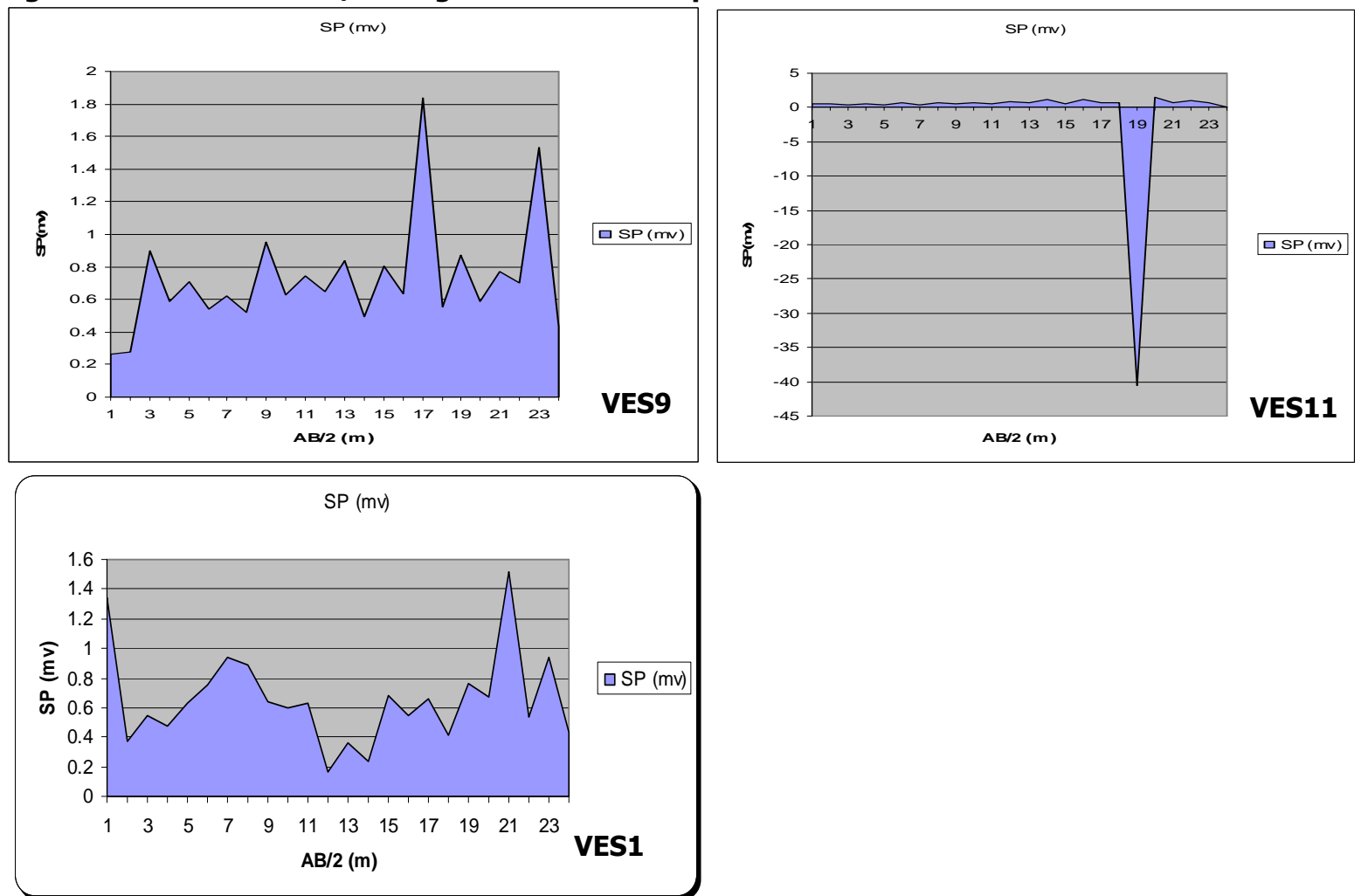

Figure 5: SP data plots for VES points on first Profile 


\section{DISCUSSION}

Profile 1 showed a depth to basement of $100 \mathrm{~m}$ rising progressively to $60 \mathrm{~m}$, a little drop to $75 \mathrm{~m}$, rising again to $60 \mathrm{~m}$ until a sharp depression to $115 \mathrm{~m}$ (Figure 4 ). The profile suggested an unconfined aquifer at the extremities of this profile cross section and shows promise of high yield boreholes. SP analysis indicates fluid activity at $45 \mathrm{~m}$ in the middle of the profile $35 \mathrm{~m}$ and $70 \mathrm{~m}$ at the right extreme and $60 \mathrm{~m}$ at the left extreme.
Maximum depth to the top of Fresh Basement rocks about each sounding locations on each profile were interpolated and plotted using surfer 7.0 software to arrive at the Basement rock topography as shown in Figure 6 . The basement topography of the study area shows conformity with the geology of the area with areas of depressions being most likely points of fluid flow within the study area. The negative sign of the depth to basement is the distance of the top soil down the depths, which is negative.

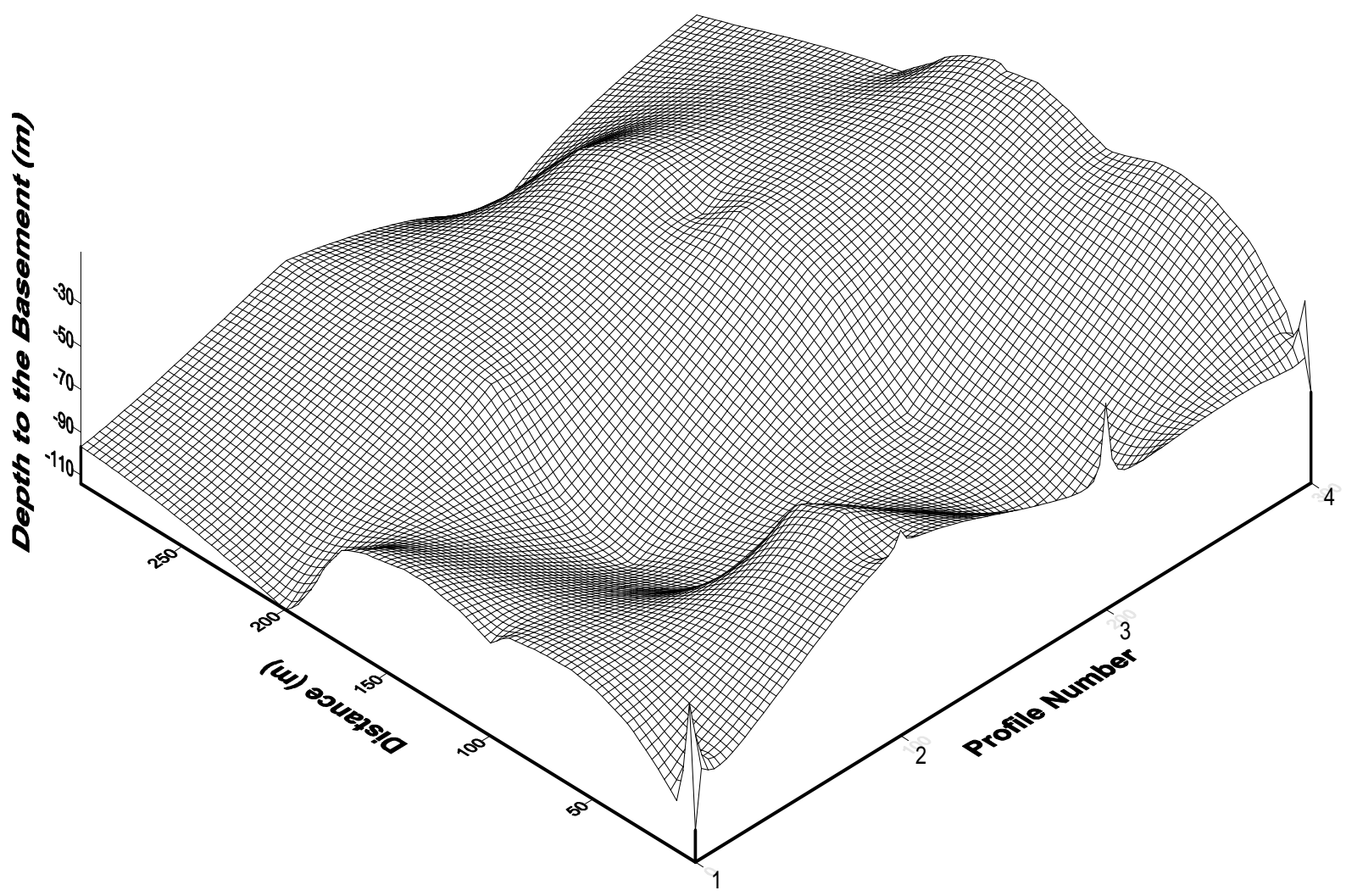

Figure 6: Basement Topography of the Study Area

Moreover, locations of peak SP values were interpolated and contoured to generate groundwater flow topography in order to generate an understanding of flow regime in the subsurface of the study area. This information in relation to the Basement topography obtained from resistivity data analysis provides complimentary guide to identification of best possible location harboring high quantity of water. Consider Figure 7 the locations with maximum depth of flow level are those located at $50.0 \mathrm{~m}$. These are regarded as best locations for sinking of boreholes. These locations coincide very well with locations of maximum depth to Basement rock in Figure 6 which were at the depths ranging from $70.0 \mathrm{~m}$ to $90.0 \mathrm{~m}$. Thus the region around the flow topography and the top of fresh Basement topography can be regarded as partially weathered layer. These are regarded as possibly maximum depth for the boreholes. In line with these assumptions, the recommended possible depths for the boreholes at the selected location ranged between $60.0 \mathrm{~m}$ to $80.0 \mathrm{~m}$. There is need also to take note that the study area varies at various points in terms of depth to the basement hence no particular depth can be assumed except well guided by geophysical surveys, the varying depths and yield of the twelve boreholes within the study area is a clear indicator of this fact as shown in the results analysis. This has been furthermore buttressed by the flow topography in correlation with the Basement topography. 


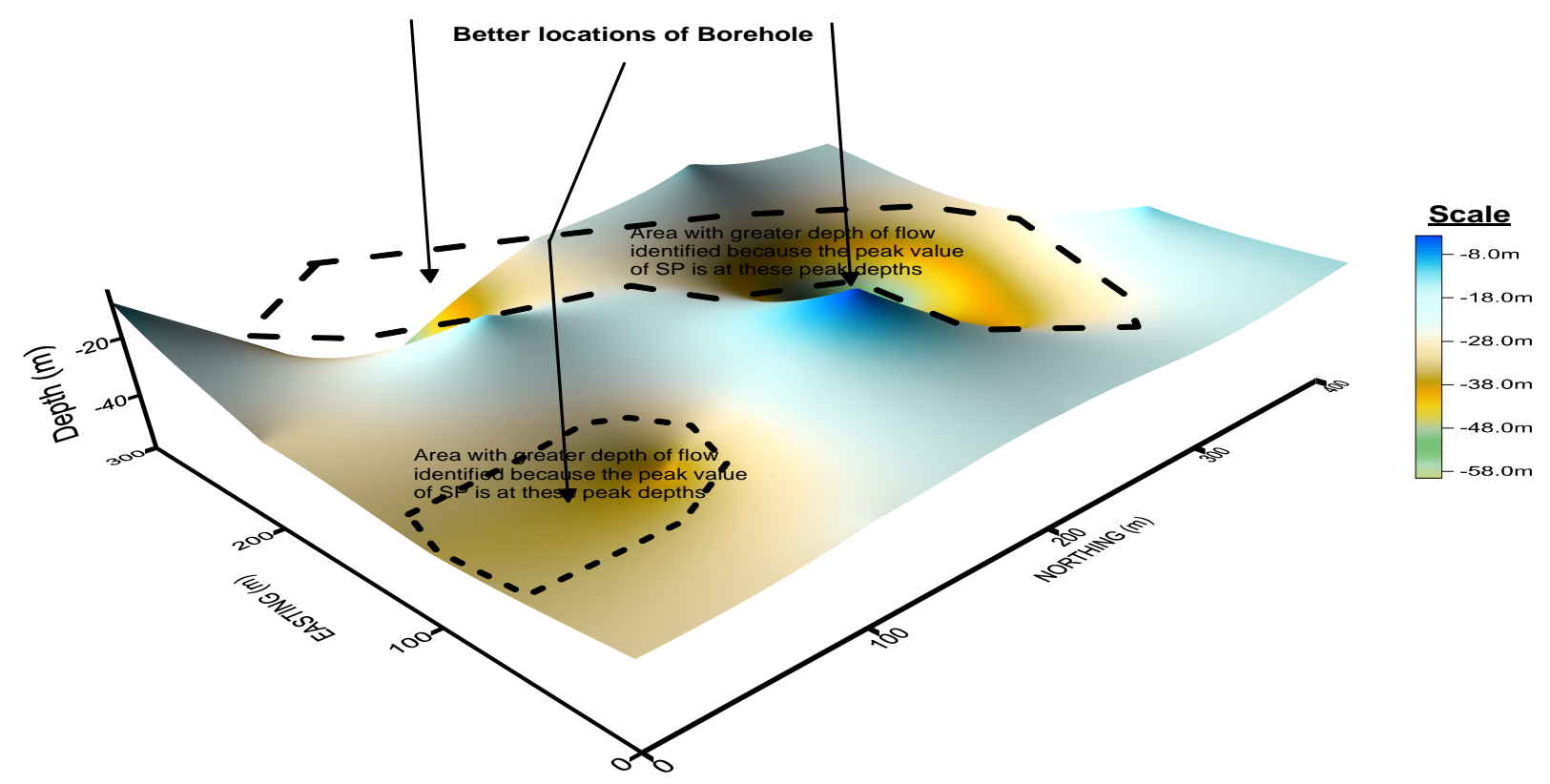

\section{CONCLUSIONS}

The previous attempts at identifying the depth to the basement were not in real fact necessarily the basement; they most likely hit the partially weathered layer as identified in this work and misconstrued it for the basement complex. This has been erroneously used as a guide for drilling boreholes by local borehole drilling companies.

The study clearly showed that the area around the proposed site for Faculty of Medicine across biological sciences right through to the central Mosque have complimentary parameters/features which favor high groundwater accumulation and storage as well as sports complex area. These areas were recommended for groundwater exploration, whereas areas about Faculty of Science complex, the boy's hostel area show very little indication of sustainable groundwater availability. The recommended depth range for water exploration was in excess of $18.0 \mathrm{~m}$ to $42.0 \mathrm{~m}$ to the presumed value used by borehole drillers as general guide.

\section{REFERENCES}

Alkali S.C., Kamfut, N.M. and Yusuf, A.K. (1997). A Geoelectric Investigation of groundwater at Kwasauri near Kano, Northern Nigeria, Journal of NAH, Vol. 8, No. 1, 11-18.

Emenike, E.A. (2001). Geophysical exploration for groundwater in sedimentary environment: A case study from Nnaka over Nnaka formation in Anambra Basin, South Eastern Nigeria, Global Journal of pure and applied Science, Vol. 7, No $1,1-12$.

John, M. (2003). Field Geophysics. Wiley and Sons Publishers, Sussex, England.

\section{RECOMMENDATIONS}

1. The study area is surrounded by congested settlements (Dorayi, Jan Bulo, Kabuga, and Dukawaya). In addition there is drastic increase in enrolment and people within the campus. Thus there is the need for proper and continuous water quality assessment.

2. A more comprehensive study should be instituted that will cover the whole campus and its surroundings in order generate better understanding of the underground water regime of the campus. This is important as this study covered only the academic area

3. The study used $100.0 \mathrm{~m}$ grid size for the investigation points, however, to generate a more comprehensive a shorter grid size, about $50.0 \mathrm{~m}$ is recommended. To this end, in order to increase the level of confidence as regards the knowledge of basement surface topography and stratigraphy of the site, this study recommends application of electrical imaging technique to be compliment by seismic imaging technique. This proved useful as vadose zone cannot be discriminate from zone of saturation from resistivity method alone.

Kasonta, L.J. and Kasonta, D.S. (1999). Geophysics Locates water in Dares Salam; 25th WEDC Conference, Addiss Ababa, Ethiopia

Keller C.V and Frischnecht F.C. (1966); Electrical Methods in Geophysical Prospecting. Pergamon Press, Oxford, England.

Obiora, D.N. and Onwuka O.S. (2005); Groundwater Exploration in Ikorodu, Lagos; A surface geophysical survey Contribution, The Pacific Journal of Science and Technology, Vol. 6, No. $1,86-92$.

William, L. (1997). Fundamentals of Geophysics. Cambridge University Press, London.

www.kanostate.net, (2001); Consulted 15/10/2010 